\title{
ANALISIS PERBANDINGAN RASIO RENTABILITAS PADA PT BPD SUMATERA BARAT TAHUN 2012-2014
}

\author{
Siti Hikmah Mulya Roza, Jhon Fernos \\ Akademi Keuangan Perbankan "Pembangunan" Padang \\ Jhonfernos@akbpstie.ac.id
}

\begin{abstract}
The company's ability to generate net income in 2012 and 2014 does not include BI's efficient standards because of the low value of NPM due to higher sales or costs.

The net profit earned from the company's operations with the amount of assets used to generate profits is not efficient because the value is lower than the BI standard because the amount of assets is greater than the profit obtained.

The company's ability to generate profits from operating return on capital in 2013 was very efficient because the value of ROE in 2013 was above the standard of Bank Indonesia.
\end{abstract}

Keywords: Bank, Rentability Ratio

\section{PENDAHULUAN}

Bank merupakan salah satu keuangan yang mempunyai peranan penting di dalam perekonomian suatu Negara sebagai lembaga perantara keuangan.Bank dalam Pasal 1 ayat (2) UU No. 10 Tahun 1998 tentang perubahan UU No. 7 Tahun 1992 tentang perbankan adalah badan usaha yang menghimpun dana dari masyarakat dalam bentuk simpanan dan meyalurkannya kepada masyarakat dalam bentuk kredit dan atau bentuk-bentuk lain dalam rangka meningkatkan taraf hidup rakyat banyak. Jenis bank berdasarkan UU No 10 Tahun 1998 tentang perubahan UU No. 7 Tahun 1992 ada dua jenis yaitu : bank yang melakukan usaha secara konvensional. dan bank yang melakukan usaha secara syariah.

Bank konvensional dapat didefenisikan seperti pada pengertian bank umum pada pasal 1 ayat 3 Undang-Undang No. 10 tahun 1998 dengan menghilangkan kalimat "dan atau berdasarkan prinsip syariah",yaitu bank yang melaksanakan kegiatan usaha secara konvensional yang dalam kegiatannya memberikan jasa dalam lau lintas pembayaran.Berdasarkan Undang-Undang Reublik Indonesia No.21 tahun 2008 Perbankan Syariah adalah segala sesuatu yang menyangkut tentang Bank Syariah dan Unit Usaha Syariah,mencakup kelembagaan,kegiatan usaha,serta cara dan proses dalam melaksanakan kegiatan usahanya.

Laporan Keuangan adalah dua daftar yang disusun oleh akuntan pada akhir periode untuk suatu perusahaan.Kedua daftar itu adalah daftar neraca atau daftar periode keuangan dan daftar pendapatan atau daftar laba-rugi.Pada akhir-akhir ini sudah menjadi kebiasaan bagi persoroan-perseroan untuk menambahkan daftar ketiga yaitu daftar surplus atau daftar laba yang tidak dibagikan (laba yang ditahan).

Pengertian analisis rasio menurut kamus istilah keuangan dan investasi adalah metode analisis yang digunakan dalam membuat penilaian kredit dan investasi dan menggunakan hubungan antara angka-angka yang ditemukan dalam laporan keuangan 
untuk menentukan nilai dan mengkaji risiko. Rasio-rasio tersebut dibandingkan dengan rasio masa sebelumnya serta rasio perusahaan lain agar dapat mengungkapkan kecenderungan dan mengidentifikasi kejanggalan.

Rentabilitas suatu perusahaan diukur dengan kesuksesan perusahaan dan kemampuan menggunakan aktivanya secara produktif,dengan demikian rentabilitas suatu perusahaan dapat diketahui dengan memperbandingkan antara laba yang di peroleh dalam suatu periode dengan jumlah aktiva atau jumlah modal perusahaan tersrbut.Masalah Rentabilitas adalah berhubungan untuk mengukur effisiensi penggunaan modal dalam suatu perusahaan dengan memperbandingkan antara laba dengan modal yang digunakan dalam operasi,oleh karena itu keuntungan yang besar tidak menjamin atau bukan merupakan ukuran bahwa perusahaan tersebut rendabel.

Tabel 1

Data laporan Keuangan

PT BPD Sumatera Barat Tahun 2012 - 2014

\begin{tabular}{lllll}
\hline \multirow{2}{*}{ Keterangan } & \multicolumn{3}{c}{ Tahun } \\
\cline { 2 - 5 } & 2012 & 2013 & 2014 \\
\hline Laba Setelah Pajak/Laba Bersih & $\mathrm{Rp} 285.023$ & $\mathrm{Rp} 305.496$ & $\mathrm{Rp} \mathrm{276.437}$ \\
Total Penjualan Bersih & $\mathrm{Rp} \mathrm{5.570.407}$ & $\mathrm{Rp} \mathrm{4.878.371}$ & $\mathrm{Rp} \mathrm{7.463.156}$ \\
Total Asset & $\mathrm{Rp} \mathrm{14.455.986}$ & $\mathrm{Rp} 16.331 .590$ & $\mathrm{Rp} \mathrm{18.063.811}$ \\
Modal sendiri & $\mathrm{Rp} \mathrm{2.000.000}$ & $\mathrm{Rp} 2.000 .000$ & $\mathrm{Rp} \mathrm{2.000.000}$ \\
\hline
\end{tabular}

Sumber : Data hasil olahan

Dari tabel 1. diatas pada tahun 2013 -2014 menunjukan laba bersih setelah pajak terjadi penurtunan dari Rp. 305.496 menjadi 276.437 dan total penjualan bersih sebaliknya terjadi peningkatan dari $\mathrm{Rp}, 4.878 .371$ menjadi Rp. 7.463.156 dan tola asset naik dari 16.331.590 menjadi 18.063.811 sedangkan modal sendiri tetap

Dari pengelolaan dana yang dilakukan oleh PT. BPD Sumatera Barat dapat dinilai tingkat kesehatan bank tersebut. Dimana perlu dilakukan penilaian terhadap faktor - faktor yang menentukan tingkat kesehatan bank. Dari uraian diatas, penulis tertarik untuk mengetahui bagaimana kemampuan PT. BPD Sumatera Barat dalam menggunakan modalnya secara serta efisien serta menggunakan aktivanya secara produktif untuk menghasilkan laba selama periode tertentu dengan tujuan perusahaan tersebut dapat beroperasi secara stabil dan mampu mengembalikan semua hutang - hutangnya kepada pihak lain. Maka penulis berkeinginan untuk menganalisis laporan keuangan PT. BPD Sumatera Barat. Untuk itu, penulis memberikan judul proposal ini dengan "Analisa Laporan Keuangan Berdasarkan Rasio Rentabilitas Pada PT. BPD Sumatera Barat Tahun 2013 - 2015”. 
Adapun yang menjadi permasalahan yang akan penulis bahas dalam penelitian ini yaitu : bagaimana Analisis Perbandingan Rasio Rentabilitas Pada Pt Bpd Sumatera Barat Tahun 2012-2014

\section{LANDASAN TEORI Pengertian Bank}

Bank merupakan salah satu lembaga keuangan yang mempunyai peranan penting di dalam perekonomian suatu Negara sebagai lembaga perantara keuangan. Bank dalam pasal 1 ayat (2) UU No. 10 Tahun 1998 tentang perubahan UU No. 7 Tahun 1992 tentang perbankan adalah badan usaha yang menghimpun dana dari masyarakat dalam bentuk simpanan dan menyalurkannya kepada masyarakat dalam bentuk kredit dan atau bentukbentuk lain dalam rangka meningkatkan taraf hidup rakyat banyak.

Bank dapat dibedakan dalam beberapa jenis yaitu :

\section{Bank Sentral}

Bank Sentral adalah Bank yang tugasnya mengeluarkan uang kertas serta uang logam untuk alat pembayaran sah di sebuah Negara. Tugas lainnya adalah menjaga konversi uang terhadap nilai emas dan perak.

2. Bank Umum

Bank Umum adalah institusi keuangan yang berwenang memberikan pinjaman atau melakukan investasi dari dana tabungan yang berhasil dihimpunnya, namun juga bisa memberikan pinjaman dengan mengeluarkan sendiri yang dinamakan uang giral.

3. Bank Perkreditan Rakyat (BPR)

Bank Perkreditan Rakyat adalah bank yang menjalankan usahanya scara tradisional atau bisa juga dengan mendasarkannya pada kaidah islam dimana aktifitasnya tak menyediakan jasa pada lalu lintas pembayaran.

4. Bank Syariah

Bank yang bekerja sesuai dengan kaidah bagi hasil yang sejalan dengan prinsip islami mengenai hukum riba.

\section{Fungsi Bank}

Fungsi bank secara umum adalah menghimpun dana dari masyarkat luas (funding) dan menyalurkan dalam bentuk pinjaman atau kredit (lending) untuk berbagai tujuan. Tetapi sebenarnya fungsi bank dapat dijelaskan dengan lebih spesifik seperti yang diungkapkan oleh Y. Sri Susilo, Sigit Triandaru, dan A. Totok Budi Santoso (2006), yaitu sebagai berikut :

\section{Agent Of Trust}

Dasar utama kegiatan perbankan adalah trust atau kepercayaan, baik dalam hal menghimpun dana maupun penyaluran dana.

2. Agen Of Development

Kelancaran kegiatan investasi, distribusi, konsumsi ini tidak lain adalah kegiatan pembangunan perekonomian masyarakat.

3. Agent Of Service

Selain menghimpun dan menyalurkan dana, bank juga memberikan penawaran jasa-jasa perbankan yang lain kepada masyarakat seperti jasa pengiriman uang, jasa penitipan barang berharga dan lain-lain.

\section{Pengertian Laporan Keuangan}


Laporan keuangan adalah laporan yang menunjukkan kondisi keuangan perusahaan pada saat ini atau dalam suatu periode tertentu. (Kasmir, 2008 : 7). Laporan keuangan merupakan hasil akhir dari suatu proses pencatatan, yang merupakan suatu ringkasan dari transaksi-transaksi keuangan yang terjadi selama tahun buku yang bersangkutan.

Menurut Kasmir ( 2008:10 ), secara umum laporan keuangan bertujuan untuk memberikan informasi keuangan suatu perusahaan, baik pada saat tertentu maupun pada periode tertentu. Berikut ini beberapa tujuan pembuatan atau penyusunan laporan keuangan, yaitu :

1. Memberikan informasi tentang jenis dan jumlah aktiva (harta) yang dimiliki perusahaan pada saat ini;

2. Memberikan informasi tentang jenis dan jumlah kewajiban dan modal yang dimiliki perusahaan saat ini;

3. Memberikan informasi tentang jenis dan jumlah pendapatan yang diperoleh pada suatu periode tertentu;

4. Memberikan informasi tentang jumlah biaya dan jenis biaya yang dikeluarkan perusahaan dalam suatu periode tertentu;

5. Memberikan informasi tentang perubahan-perubahan yang terjadi atas aktiva, pasiva, dan modal perusahaan;

6. Memberikan informasi tentang kinerja manajemen perusahaan dalam suatu periode;

7. Memberikan informasi tentang catatan-catatan atas laporan keuangan;

8. Informasi keuangan lainnya;

\section{Bentuk-Bentuk Laporan Keuangan}

Ada banyak laporan keuangan yang dikeluarkan perusahaan, tetapi yang umum digunakan adalah :

1. Laporan Laba Rugi

Munawir mendefinisikan laporan rugi laba adalah :'Laporan rugi laba merupakan suatu laporan yang sistematis tentang penghasilan, biaya, rugi laba yang diperoleh organisasi suatu perusahaan selama periode tertentu". (2000:26)

2. Neraca

Munawir menyatakan bahwa : Neraca adalah laporan yang sistematis tentang aktiva, hutang serta modal dari suatu laporan yang disusun pada suatu saat tertentu". (2000 : 13) Menurut Harnanto, neraca adalah :"Suatu laporan yang disusun dengan maksud untuk menunjukkan keadaan (posisi) finansial perusahaan pada saat tanggal tertentu". (1984 : I) Bentuk neraca yang ada pada perusahaan-perusahaan tidak ada yang seragam, bentuk dan susunannya tergantung pada tujuan yang akan dicapai. Bentuk neraca yang lazim digunakan adalah sebagai berikut :

a. Bentuk skontro, dimana semua aktiva tercantum sebelah kiri/debet dan hutang serta modal tercantum sebelah kanan/kredit.

b. Bentuk vertikal, dalam bentuk ini semua aktiva Nampak dibagian atas yang selanjutnya diikuti hutang jangka pendek, hutang jangka panjang serta modal.

3. Laporan Perubahan Laba Ditahan

Laporan perubahan laba ditahan menunjukkan laba yang diperoleh perusahaan dan deviden yang dibayarkan selama satu periode sehingga menyebabkan perubahan laba ditahan.

4. Laporan Arus Kas 
Laporan arus kas merupakan ringkasan arus kas selama satu periode. Laporan ini menunjukkan perubahan arus kas yang terjadi karena kegiatan operasi, investasi dan financial sehingga posisi/saldo kas berubah.

Tujuan yang paling utama dari laporan arus kas ini adalah untuk memberikan informasi penting atau yang relevan mengenai penerimaan-penerimaan dan pengeluaranpengeluaran kas selama periode berjalan. Adapun bentuk penyajian laporan arus kas ini dibagi menjadi empat, yakni :

a. Diklasifikasikan berdasarkan aktivitas operasi seperti penjualan tunai, pelunasan hutang, pembayaran biaya-biayanya.

b. Diklasifikasikan berdasarkan aktivitas investasi seperti menginvestasikan dana yang tidak terpakai.

c. Diklasifikasikan berdasarkan aktivitas pendanaan seperti dana pinjaman dari luar perusahaan (Hutang jangka panjang).

d. Disesuaikan dengan bisnis perusahaan

\section{Pengertian Analisa Laporan Keuangan}

Munawir mengemukakan pengertian analisa laporan keuangan adalah "Mempelajari hubungan-hubungan di dalam suatu setiap laporan keuangan pada suatu saat tertentu dan kecenderungan-kecenderungan dari hubungan ini sepanjang waktu". (1998)

Menurut Harahap analisa laporan keuangan yaitu "menguraikan pos-pos laporan keuangan menjadi unit informasi yang lebih kecil dan melihat hubungan yang bersifat signifikan atau yang mempunyai makna antara satu dengan yang lain baik antaradata kuantitatif maupun non kuantitatif dengan tujuan untuk mengetahui kondisi keuangan lebih dalam yang sangat penting dalam proses menghasilkan keputusan yang tepat".(1998:3)

Menurut Djahidin analisa laporan keuangan adalah "Analisa laporan keuangan yang mencakup penerapan metode dari teknik analitis atas laporan keuangan dan data lainnya untuk melihat dari laporan itu ukuran-ukuran dan hubungan tertentu yang sangat berguna dalam proses pengambilan keputusan”. (1983).

\section{Tujuan Analisa Laporan}

Berikut ini tujuan dari analisa laporan keuangan, yaitu :

a. Untuk mengetahui posisi keuangan perusahaan dalam satu periode tertentu;

b. Untuk mngetahui kelemahan-kelemahan perusahaan;

c. Untuk mengetahui kekuatan-kekuatan yang dimiliki;

d. untuk mengetahui langkah-langkah perbaikan apa saja yang perlu dilakukan untuk penilaian kinerja manajemen.

\section{METODE PENELITIAN}

Dalam pengumpulan data dan bahan untuk melakukan penelitian ini, digunakan metode - metode pengumpulan data sebagai berikut :

1. Metode Pengumpulan Data

a. Studi Lapangan (Field Research)

Peninjauan langsung ke objek penelitian dipilih untuk meneliti hasil data primer dan membantu penulis melengkapi data yang diperlukan. Adapun cara riset ini adalah dengan mewawancarai pihak - pihak yang berkepentingan dalam hal ini adalah perusahaan atau instansi yang terkait.

b. Studi Kepustakaan (Library Research) 
Penilaian yang dilakukan ke perpustakaan beberapa buku - buku ilmiah dan tulisan - tulisan yang berhubungan dengan pembahasan yang dilakukan.

2. Metode Analisa Data

Dalam menganalisa data, penulis menggunakan analisis data kuantitatif sebagai metode penelitian yang menjelaskan secara deskriptif mengenai bagaimana analisa laporan keuangan pada PT. BPD Sumatera Barat. Metode analisis ditinjau dari dua segi yang berbeda yaitu antara teori dan praktek yang perlu diterapkan, sehingga dapat diketahui sejauh mana pelaksanaannya, apakah perbedaan yang timbul menyangkut prinsip dasar konsep itu sendiri, pertanyaan itu akan terjawab, selanjutnya dari hasil analisa itu digunakan sebagai dasar pengambilan kesimpulan dan saran.

\section{HASIL DAN PEMBAHASAN}

Pengertian rentabilitas adalah kemampuan perusahaan dalam menghasilkan keuntungan dengan semua modal yang bekerja di dalamnya. Pengertian rentabilitas menurut Sofyan Syafri Harahap (2007) yaitu: Rasio Rentabilitas atau disebut juga Profitabilitas menggambarkan kemampuan perusahaan mendapatkan laba melalui semua kemampuan, dan sumber yang ada seperti kegiatan penjualan, kas, modal, jumlah karyawan, jumlah cabang, dan sebagainya. Rasio yang menggambarkan kemampuan perusahaan menghasilkan laba dan di sebut juga Operating Ratio.

1. Net Profit Margin

a. Tahun 2012

$$
\begin{aligned}
\mathrm{NPM} & =\frac{\text { Laba setelah pajak }}{\text { Penjualan bersih }} \times 100 \% \\
& =\frac{R p 285.023}{R p 5.570 .407} \times 100 \% \\
& =5,118 \%
\end{aligned}
$$

Angka di atas memberikan arti bahwa setiap Rp 1 nilai penjualan,5,118\% diantaranya (atau Rp 0.05118) akan menghasilkan laba setelah pajak.Perlu dipahami bahwa ratio ini merefleksikan: harga pokok penjualan,bebanbeban operasi,beban keuangan (beban bunga) dan pajak.

b. Tahun 2013

$$
\mathrm{NPM}=\frac{\text { Laba setelah pajak }}{\text { Penjualan bersih }} \chi 100 \%
$$




$$
\begin{aligned}
& =\frac{\operatorname{Rp} 305.496}{\operatorname{Rp~} 4.878 .371} \times 100 \% \\
& =6,262 \%
\end{aligned}
$$

Angka di atas memberikan arti bahwa setiap Rp 1 nilai penjualan,6,262\% diantaranya (atau $\mathrm{Rp}$ 0.06262) akan menghasilkan laba setelah pajak.Perlu dipahami bahwa ratio ini merefleksikan: harga pokok penjualan,bebanbeban operasi,beban keuangan (beban bunga) dan pajak.

c. Tahun 2014

$$
\begin{aligned}
\mathrm{NPM} & =\frac{\text { Laba setelah pajak }}{\text { Penjualan bersih }} \times 100 \% \\
& =\frac{R p 276.437}{R p 7.463 .156} \times 100 \% \\
& =3,704 \%
\end{aligned}
$$

Angka di atas memberikan arti bahwa setiap Rp 1 nilai penjualan,3,704\% diantaranya (atau $\mathrm{Rp}$ 0.03704) akan menghasilkan laba setelah pajak.Perlu dipahami bahwa ratio ini merefleksikan: harga pokok penjualan,bebanbeban operasi,beban keuangan (beban bunga) dan pajak.

2. Return On Asset (ROA)

a. Tahun 2012

$$
\begin{aligned}
\text { ROA }= & \frac{\text { Laba setelah pajak }}{\text { Total Asset }} \times 100 \% \\
= & \frac{\text { Rp 285.023 }}{\text { Rp 14.455.986 }} \times 100 \% \\
& =1,972 \%
\end{aligned}
$$

ROA pada PT BPD Sumatera Barat nilainya rendah,1,972\%,karena peruasahaan tidak bisa menggunakan atau memanfaatkan aktiva yang dimilikinya di dalam mengahasilkan keuntungan setelah pajak. 
b. Tahun 2013

$$
\begin{aligned}
\text { ROA }= & \frac{\text { Laba setelah pajak }}{\text { Total Asset }} \times 100 \% \\
& =\frac{\operatorname{Rp} 305.496}{\operatorname{Rp} 16.331 .590} \times 100 \% \\
& =1,871 \%
\end{aligned}
$$

ROA pada PT BPD Sumatera Barat nilainya rendah,1,871\%,karena peruasahaan tidak bisa menggunakan atau memanfaatkan aktiva yang dimilikinya di dalam mengahasilkan keuntungan setelah pajak.

c. Tahun 2014

$$
\begin{aligned}
\text { ROA }= & \frac{\text { Laba setelah pajak }}{\text { Total Asset }} \times 100 \% \\
= & \frac{\operatorname{Rp} 276.437}{\operatorname{Rp~} 18.063 .811} \times 100 \% \\
& =1,503 \%
\end{aligned}
$$

ROA pada PT BPD Sumatera Barat nilainya rendah, $1,503 \%$ karena peruasahaan tidak bisa menggunakan atau memanfaatkan aktiva yang dimilikinya di dalam mengahasilkan keuntungan setelah pajak.

3. Return on Equity (ROE)

a. Tahun 2012

$$
\begin{aligned}
\mathrm{ROE}= & \frac{\text { Laba setelah pajak }}{\text { Modal sendiri }} \times 100 \% \\
& =\frac{\operatorname{Rp} 285.023}{\operatorname{Rp} 2.000 .000} \times 100 \% \\
& =14,251 \%
\end{aligned}
$$

b. Tahun 2013 


$$
\begin{aligned}
\text { ROE } & =\frac{\text { Laba setelah pajak }}{\text { Modal sendiri }} \times 100 \% \\
& =\frac{\operatorname{Rp~} 305.496}{\operatorname{Rp} 2.000 .000} \times 100 \% \\
& =15,275 \%
\end{aligned}
$$

c. Tahun 2014

$$
\begin{aligned}
\text { ROE } & =\frac{\text { Laba setelah pajak }}{\text { Modal sendiri }} \times 100 \% \\
& =\frac{\text { Rp } 276.437}{\operatorname{Rp~} 2.000 .000} \times 100 \% \\
& =13,822 \%
\end{aligned}
$$

ROE $<2014<$ ROE $2012<$ ROE 2013

Dari analisa di atas dapat disimpulkan bahwa nilai ROE tahun 2012 14,251\%,tahun 2013 15,275\% dan tahun 2014 13,822\%.Artinya kemampuan PT BPD Sumatera Barat pada tahun 2013 memperoleh keuntungan dari modal sendiri yang digunakan oleh bank

\begin{tabular}{|c|c|c|c|c|c|c|c|}
\hline \multirow[t]{2}{*}{ Rasio } & \multirow[t]{2}{*}{$\begin{array}{l}\text { Rata- } \\
\text { Rata } \\
\text { Industri }\end{array}$} & Tahun & \multirow[t]{2}{*}{ Evaluasi } & Tahun & \multicolumn{2}{|l|}{ Evaluasi } & \multirow[t]{2}{*}{ Evaluasi } \\
\hline & & 2012 & & 2013 & & 2014 & \\
\hline .NPM & $3,92 \%$ & $5,118 \%$ & $\begin{array}{l}\text { Sangat } \\
\text { bagus }\end{array}$ & 6,262 & $\begin{array}{l}\text { Sangat } \\
\text { bagus }\end{array}$ & 3,70 & Buruk \\
\hline ROA & $5,08 \%$ & $1,972 \%$ & $\begin{array}{l}\text { Buruk } \\
\text { Sangat }\end{array}$ & $1,871 \%$ & $\begin{array}{l}\text { Buruk } \\
\text { Sangat }\end{array}$ & $1,503 \%$ & $\begin{array}{l}\text { Buruk } \\
\text { Sangat }\end{array}$ \\
\hline ROE & $8,32 \%$ & $14,251 \%$ & Bagus & $15,275 \%$ & Bagus & $13,822 \%$ & Bagus \\
\hline
\end{tabular}
tersebut,karena pada ROE tahun 2013 lebih efisien dari standar Bank Indonesia

Tabel. 2

Perkembangan Rasio Rentabilitas

Bank pembangunan Daerah propinsi Suymatera barat Tahun 2012 - 2014

Sumber : Data olahan 
Melalui perbandingan antara ringkasan rasio keuangan PT BPD Sumatera Barat,maka hasil perbandingan dapat diuraikan sebagai berikut :

1. Marjin keuntungan PT BPD Sumatera Barat tahun 2012 dan 2013 relatif tinggi dari rata-rata industri,namun pada tahun 2014 relatif rendah dari rata-rata industri.

2. Kemampuan PT BPD Sumatera Barat untuk menghasilkan laba dari total aktiva,perusahaan ini belum mampu menghasilkan tingkat keuntungan lebih bagus dari rata-rata industri.

3. Jika dilihat dari sudut kemampuan PT BPD Sumatera Barat untuk menghasilkan laba disbanding modal sendiri yang berasal dari pemilik,perusahaan ini mampu menghasilkan tingkat keuntungan lebih bagus di banding rata-rat industri sejenis.

\section{SIMPULAN}

Setelah melaksanakan analisa terhadap laporan keuangan pada PT BPD Sumatera

Barat penulis dapat menarik kesimpulan

1. Kemampuan perusahaan dalam menghasilkan laba bersih pada tahun 2012 dan 2014 belum termasuk pada standar efisien BI karena rendahnya nilai NPM di sebabkan penjualan atau biaya-biaya lebih tinggi.

2. Laba bersih yang di peroleh dari operasi perusahaan dengan jumlah aktiva yang digunakan untuk menghasilkan keuntungan belum efisien karena nilinya lebih rendah dari standar BI yang disebabkan jumlah aktivanya lebih besar dari laba yang di dapat.

3. Kemampuan perusahaan dalam menghasilkan laba dari operasi pengembalian modal pada tahun 2013 sangat efisien karan nilai ROE pada tahun 2013 di atas standar bank Indonesia.

\section{DAFTAR PUSTAKA}

Abdullah, Faisal. (2003). Manajemen Perbankan (Teknik Analisis Kinerja Keuangan Bank). Universitas Muhammadiyah Malang (UMM) Press Malang.

Agus, Sartono, 2002, Manajemen Keuangan : Teori dan Aplikasi, edisi keempat, cetakan pertama, penerbit : BPFE, Yogyakarta.

Arifin, I. Z., \& Marlius, D. (2017). Analisis Kinerja Keuangan PT. Pegadaian Cabang Ulak Karang. https://doi.org/10.31227/osf.io/n2peu

Astuti, Dewi. 2004. Manajemen Keuangan Perusahaan. Jakarta: Ghalia Indonesia. Kasmir. 2009. Analisis Laporan Keuangan.Jakarta: Rajawali Pers.

Djahidin, 1983, Analisa Laporan Keuangan.Ghalia Indonesia, Jakarta.Harnanto, 1984, Analisis Kinerja Keuangan Dan Perencanaan Keuangan Perusahaan.Edisi Pertama, BPFE Yogyakarta.

Handayani, M., \& Marlius, D. (2017). Analisis Tingkat Kesehatan PT. BPR Batang Kapas. https://doi.org/10.31227/osf.io/bq48z 
Ikatan Akuntan Indonesia, 2009. Standar Akuntansi Keuangan (per 1 September 2009), Salemba Empat, Jakarta.

Iswari, M., \& Fernos, J. (2019). Analisis Tingkat Kesehatan Bank Pada PT. Bank Pembangunan Daerah Sumatera Barat. https://doi.org/10.31227/osf.io/ja7ty

Munawir, 2000, Analisa Laporan Keuangan, Edisi Keempat, Liberty Yogyakarta.

Putri, Y. A., \& Marlius, D. (2018). Analisis Tingkat Kesehatan Bank Pada PT. Bank Perkreditan Rakyat (BPR) Jorong Kampuang Tangah Pariaman Cabang Padang. https://doi.org/10.31227/osf.io/r98pv

Sawir, Agnes, 2009. Analisa Kinerja Keuangan dan Perencanaan keauangan Perusahaan, PT. Gramedia Pustaka Utama, Jakarta.

Sawir, A., 2001, Analisa Kinerja Keuangan dan Perencanaan Keuangan Perusahaan, PT. Gramedia Pustaka Utama.

Suherti, E., \& Fernos, J. (2019). Analisa Rasio Terhadap Laporan Keuangan Pada PT. Bank Pembangunan Daerah Sumatera Barat. https://doi.org/10.31227/osf.io/9zte8 